\section{FIRST REPORT OF THREE REDLISTED TREE SPECIES FROM SWAMPY RELICS OF GOA STATE, INDIA}

\author{
Ashish Prabhugaonkar ${ }^{1}$, Divakar K. Mesta ${ }^{2}$ \& \\ M.K. Janarthanam ${ }^{3}$
}

\author{
1,3 Department of Botany, Goa University, Goa 403206, India \\ ${ }^{2}$ Department of Botany, Carmel College of Arts, Science and Commerce for \\ Women, Nuvem, Goa 403604, India \\ 1 ashishprabhugaonkar@yahoo.co.in, ${ }^{2}$ divakarmesta@rediffmail.com, \\ ${ }^{3}$ mkjana@yahoo.com (corresponding author)
}

The Myristica swamps are probably the remains of the most ancient forests of the Western Ghats with a history of more than 140 million years (Chandran et al. 1999). These swamp forests were described from Travancore (Krishnamoorthy 1960) and later from the valleys of Shendurney, Kulathupuzha and Anchal ranges of southern Kerala (Champion \& Seth 1968). Similar swamps were reported from different places along the Western Ghats (Talbot 1911; Saldanha 1984; Gadgil \& Chandran 1989) of Karnataka. The northernmost Myristica swamp so far reported in the Western Ghats is from Bambar in Satari Taluk of Goa (Santhakumaran et al. 1995, 1996). These habitats have been described as 'swampy relics' (Chandran et al. 2010) and several studies of these swamps have been made in Kerala (Krishnamoorthy 1960; Pascal 1988) and Karnataka (Singh 1996; Chandran et al. 1999; Chandran \& Mesta 2001; Vasudeva et al. 2001; Chandran et al. 2010).

Myristica swamps are the fresh water swamps represented by any of the members of the Myriticaceae like Gymnacranthera canarica (King) Warb. and Myristica fatua Houtt. var. magnifica (Bedd.) J.Sinclair (Chandran et al. 1999; Bhat \& Kaveriappa 2009). These swamps may occasionally include Myristica malabarica
Lam., M. beddomei King and Knema attenuata (Wall. ex Hook.f. \& Thomson) Warb., which are more common outside the swamps. Association of many endemic tree species in these swamps are well documented (Bourdillon 1908; Sasidharan \& Sivarajan 1996;

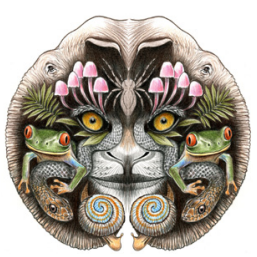

ISSN

Online 0974-7907 Print 0974-7893

OPEN ACCESS Ramesh \& Pascal 1997; Chandran \& Mesta 2001). Some of the redlisted plants in the Red Data Book of Indian Plants are associated with the swampy relics or low lying forests (Nayar \& Sastry 1987, 1990). This has been further substantiated by the discovery of a new tree species, viz., Semecarpus kathalekanensis (Dasappa \& Swaminath 2000) and discovery of two Critically Endangered tree species Madhuca bourdillonii H.J.Lam and Syzygium travancoricum from these swampy relics of Uttara Kannada (Chandran et al. 2008), far away from their original distribution records. Another rare tree species, Cassipourea ceylanica (Gardn.) Alston of Rhizophoraceae is also found associated with a Myristica swamp in Uttara Kannada (Mesta et al. 2009). Because of rich diversity, endemism and threat status of these swamps, Chandran et al. (2008) stressed on the need for intensifying efforts for locating such swampy relics.

With this background knowledge, a visit was made to a relic Myristica swamp at Brahma Karmali $\left(15^{\circ} 33.874^{\prime} \mathrm{N} \& 7^{\circ} 10.378^{\prime} \mathrm{E} ; 45 \mathrm{~m}\right)$ of Valpoi Taluka in Goa. Some interesting plants such as Gymnacranthera canarica, Semecarpus kathalekanensis Dasappa \& Swam., Syzygium travancoricum Gamble and Myristica fatua Houtt. var. magnifica (Bedd.) J. Sinclair have been located in the swamp. Elsewhere in the Western Ghats, these Myristica swamps are known to be associated with low lying primary evergreen forests in the valleys

DOI: http://dx.doi.org/10.11609/JoTT.o3376.5503-6

Editor: N.P. Balakrishnan, Ret. Joint Director, BSI, Coimbatore, India.

Date of publication: 26 February 2014 (online \& print)

Manuscript details: Ms \# 03376 | Received 06 October 2012 | Final received 17 January 2014 | Finally accepted 20 January 2014

Citation: Ashish Prabhugaonkar, Divakar K. Mesta \& M.K. Janarthanam (2014). First report of three redlisted tree species from swampy relics of Goa State, India. Journal of Threatened Taxa 6(2): 5503-5506; http://dx.doi.org/10.11609/JoTT.03376.5503-6

Copyright: @ Prabhugaonkar et al. 2014. Creative Commons Attribution 3.0 Unported License. JoTT allows unrestricted use of this article in any medium, reproduction and distribution by providing adequate credit to the authors and the source of publication.

Funding: None.

Competing Interest: The authors declare no competing interests.
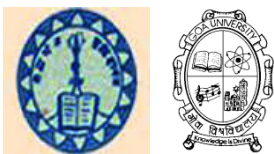

Acknowledgements: Authors acknowledge the help of Dr. K. Ravikumar, FRLHT, Bangalore and Dr. R. Vasudeva, College of Forestry, Sirsi, UAS Dharwad in various ways. The corresponding author also acknowledge the help of Ms. Asavari Kulkarni, Mr. Parag Rangnekar and Mr. Rajendra P. Kerkar for their help. 
(Krishnamoorthy 1960; Chandran et al. 2010). These swamps and the adjoining forests are known for their high evergreenness and rich tree endemism (Chandran \& Mesta 2001; Chandran et al. 2010). Unexpectedly, here in the present locality, the surrounding forests are predominantly moist deciduous type with leaf shedding species isolating and restricting the swamp to a very small pocket. The dominant tree species surrounding the swamp are Careya arborea, Terminalia elliptica, Lagerstroemia microcarpa, Dillenia pentagyna and Bridelia spp.

Gymnacranthera canarica, a Vulnerable species has been reported earlier from Goa (Naithani et al. 1997) while the occurrence of three other tree species is newly reported for Goa. The range extension of more than $150 \mathrm{~km}$ to the north of their known distribution from central Western Ghats to northern Western Ghats is significant for these threatened species. All the herbarium sheets of these plants are deposited at Goa University Herbarium.

Syzygium travancoricum Gamble is listed as a
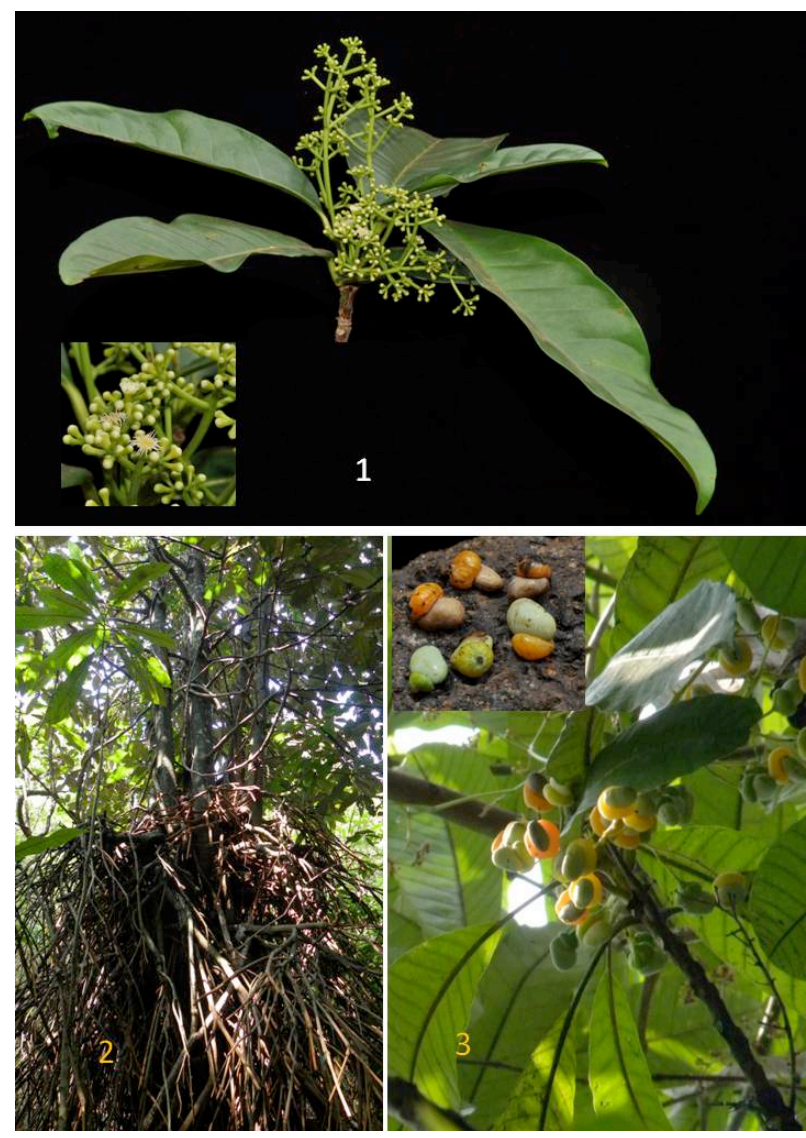

Image 1. (1) Syzygium travancoricum - Flowering twig (inset: closeup of flower); (2) Myristica fatua var. magnifica - Stilt roots;

(3) Semecarpus kathalekanensis - Fruiting twig (inset: close-up of fruits). (@ M.K. Janarthanam)
Critically Endangered tree species (C2a ver 2.3) in Red List of Threatened Species (CAMP Workshops on Medicinal Plants, India (January 1997) 1998). Prior to this assessment, it was considered as almost extinct (Nayar \& Sastry 1987). Subsequently, Chandran et al. (2008) reported this species from Uttara Kannada District of Karnataka, in the central Western Ghats, $700 \mathrm{~km}$ north of its native range. Now the present report extending its distribution range into northern Western Ghats, warrants reassessment of the status of this species.

Specimens examined: Goa University Herbarium \# 993, 10.iv.2011, Brahmakarmali, Goa, India, coll. M.K. Janarthanam, D. Mesta \& Ashish Prabhugaonkar (Images 1(1) \& 2).

Myristica fatua Houtt. var. magnifica (Bedd.) J. Sinclair has been listed as Endangered (B1+2C ver 2.3) (World Conservation Monitoring Centre 1998) under Myristica magnifica. An inhabitant of lowland evergreen swamp forests, it has been reported from Kerala and North Kanara in Karnataka. In the present location, it is very dominant in one part of the swamp with large number of stilt roots. This was found associated with $G$.

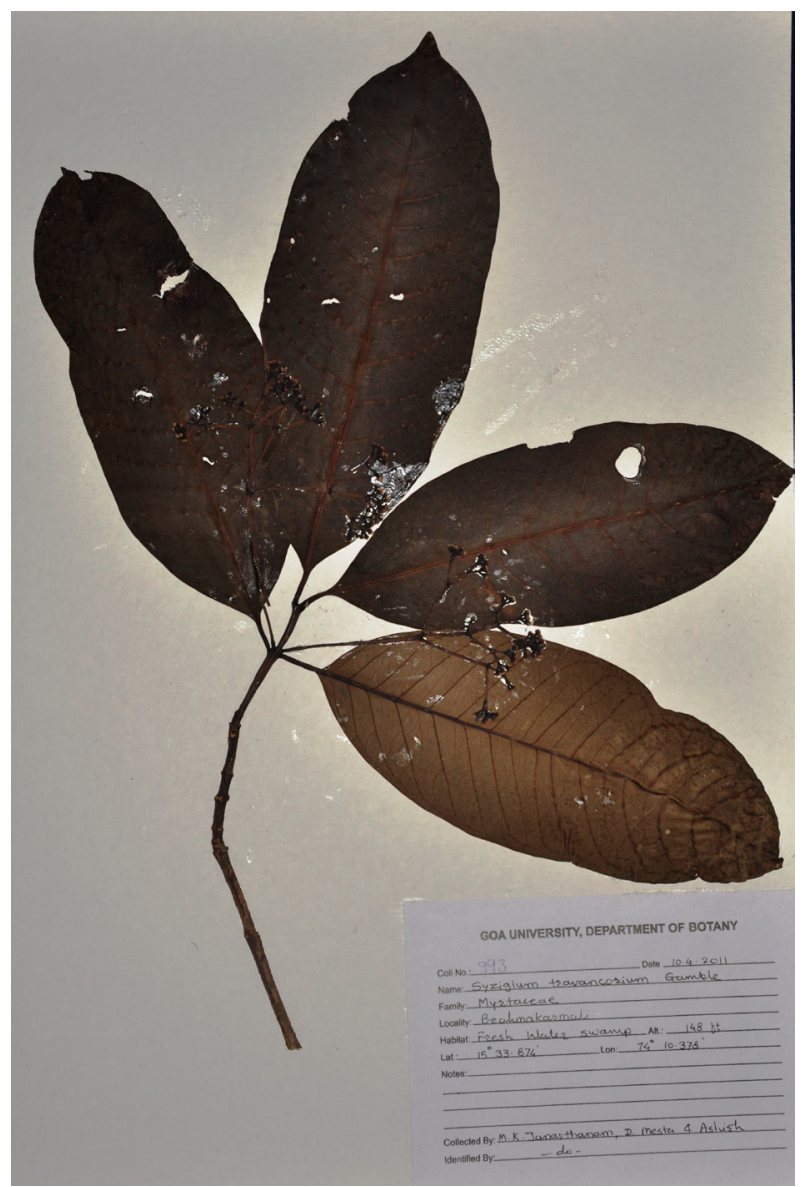

Image 2. Herbarium of Syzygium travancoricum 


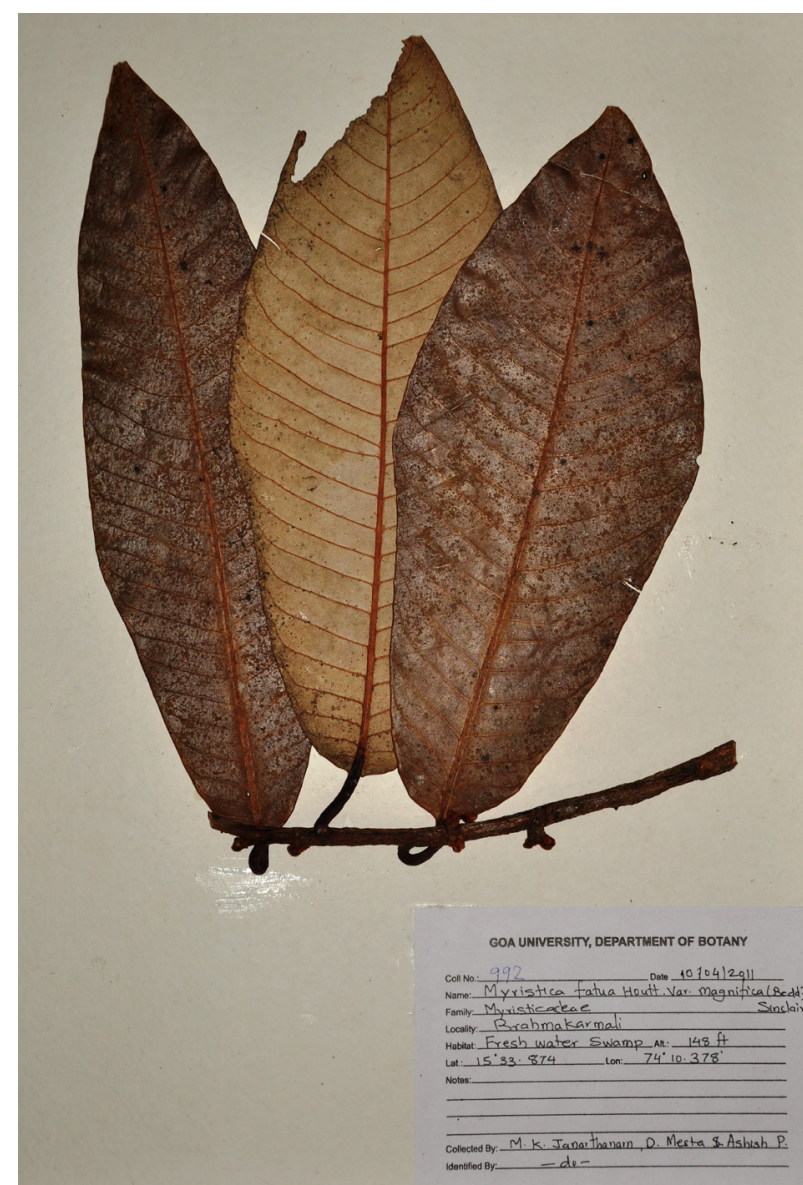

Image 3. Herbarium of Myristica fatua var. magnifica

canarica, another swamp species with its characteristic knee roots. The present record of $M$. fatua var. magnifica from northern Western Ghats is thus a valuable addition.

Specimens examined: Goa University Herbarium \# 992, 10.iv.2011, Brahmakarmali, Goa, India, coll. M.K. Janarthanam, D. Mesta \& Ashish Prabhugaonkar (Images 1(2) \& 3).

Semecarpus kathalekanensis Dasappa \& Swam. published in 2000 has been considered as a critically endangered species. Attempts have been made for its recovery using biotechnological tools (Ganeshaiah 2005). Now it has been located more than $200 \mathrm{~km}$ north of its restricted distribution range. This report thus provides hope for its conservation and maintenance of genetic diversity. Using RAPD and ISSR molecular studies Ravikanth et al. (2004) also established its taxonomic distinctness.

Specimens examined: Goa University Herbarium \# 991, 10.iv.2011, Brahmakarmali, Goa, India, coll. M.K. Janarthanam, D. Mesta \& Ashish Prabhugaonkar (Images 1(3) \& 4).

Conclusion: The fresh water swamps are thus home

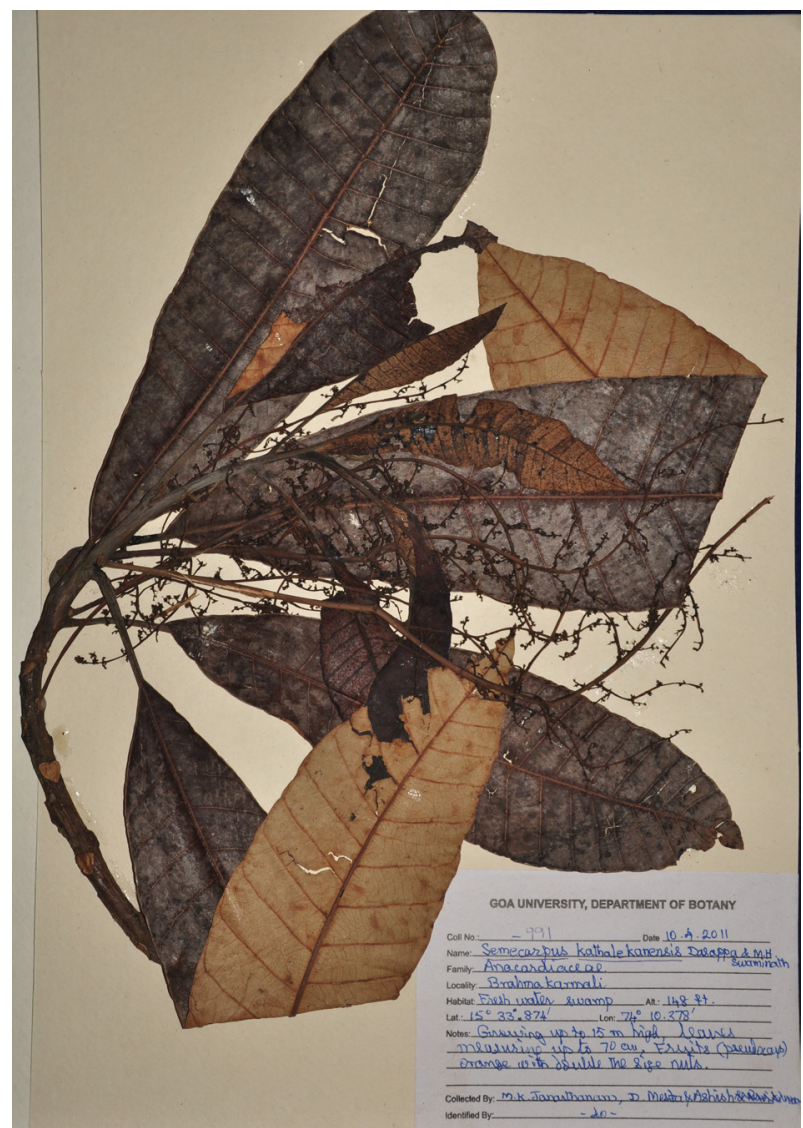

Image 4. Herbarium of Semecarpus kathalekanensis

to several threatened species. The present distribution records as given in this article add strength to this concept. A special focused inventory of all the fresh water swamps in Goa State will certainly provide much more valuable information on the northern limits of these plant species.

\section{References}

Bhat, P.R. \& K.M. Kaveriappa (2009). Ecological studies on Myristica swamp forests of Uttara Kannada, Karnataka, India. Tropical Ecology 50(2): 329-337.

Bourdillon, T.F. (1908). The Forest Trees of Travancore. The Travancore Government Press, Trivandrum, 238-239pp.

CAMP Workshops on Medicinal Plants, India (January 1997) (1998). Syzygium travancoricum. In: IUCN 2012. IUCN Red List of Threatened Species. Version 2012.1. <www.iucnredlist.org>. Downloaded on 29 September 2012.

Champion, H.G. \& S.K. Seth (1968). A Revised Survey of the Forest Types of India. Manager of Publications, New Delhi, 404pp.

Chandran, M.D.S. \& D.K. Mesta (2001). On the conservation of the Myristica swamps of the Western Ghats, pp. 1-19. In: Shankar, R.U., K.N. Ganeshaiah \& K.S. Bawa (eds.). Forest Genetic Resources: Status, Threats, and Conservation Strategies. Oxford \& IBH, New Delhi.

Chandran, M.D.S., D.K. Mesta, G.R. Rao, S. Ali, K.V. Gururaja \& T.V. Ramachandra (2008). Discovery of Two Critically Endangered Tree Species and Issues Related to Relic Forests of the Western Ghats. 
The Open Conservation Biology Journal 2: 1-8; http://dx.doi.org/ $10.2174 / 1874839200802010001$

Chandran, M.D.S., D.K. Mesta \& M.B. Naik (1999). Inventorying and Conservation of the Myristica Swamps of Uttara Kannada. Report, Forest Research and Training Institute, Bangalore.

Chandran, M.D.S., G.R. Rao, K.V. Gururaja \& T.V. Ramachandra (2010). Ecology of the swampy relic forests of Kathalekan from central Western Ghats, India. Bioremediation, Biodiversity and Bioavailability [Global Science Books], 4(special issue 1): 54-68.

Dasappa \& M.H. Swaminath (2000). A new species of Semecarpus (Anacardiaceae) from the Myristica swamps of Western Ghats of North Kanara, Karnataka, India. Indian Forester 126: 78-82.

Gadgil, M. \& M.D.S. Chandran (1989). Environmental Impact of forest based industries on the evergreen forests of Uttara Kannada district, a case study (Final Report). Department of Ecology and Environment, Bangalore.

Ganeshaiah, K.N. (2005). Recovery of endangered and threatened species: Developing a national priority list of plants and insects. Current Science 89: 559-600.

Krishnamoorthy, K. (1960). Myristica swamps in the evergreen forests of Travancore. Indian Forester 86: 314-315.

Mesta, D.K., H.V. Hegde, V. Upadhya, G.R. Rao, G.R. Hegde \& S.D. Kholkute (2009). Cassipourea ceylanica (Gardn.) Alston (1925) (Rhizophoraceae) in Karnataka. Journal of Threatened Taxa 1(10): 530-532; http://dx.doi.org/10.11609/JoTT.o2195.530-2

Naithani, H.B., K.C. Sahni \& S.S.R. Bennet (1997). Forest Flora of Goa. International Book Distributors, Dehra Dun, 501pp.

Nayar, M.P. \& A.R.K. Sastry (eds.) (1987). Red Data Book of Indian Plants. Vol. 1. Botanical Survey of India, Calcutta, 217-218pp.

Nayar, M.P. \& A.R.K. Sastry (eds). (1990). Red Data Book of Indian Plants. Vol. 3. Botanical Survey of India, Calcutta, 243-244pp.

Pascal, J.P. (1988). Wet Evergreen Forests of the Western Ghats of India: Ecology, Structure, Floristic Composition and Succession. Pondicherry: Sri Aurobindo Ashram Press, 345pp.
Ramesh, B.R. \& J.P. Pascal (1997). Atlas of Endemics of the Western Ghats (India): Distribution of Tree Species in the Evergreen and Semi - Evergreen Forests. French Institute, Pondicherry, 403pp.

Ravikanth, G., R. Vasudeva, R.U. Shaanker \& K.N. Ganeshaiah (2004). Molecular analysis of Semecarpus kathalekanensis (Anacardiaceae) - a newly described species from the Myristica swamps of Western Ghats, India. The Indian Forester 130(1): 101-104.

Saldanha, C.J. (1984). Flora of Karnataka - Volume 1. Oxford and IBH Publishing Co., New Delhi, 535pp.

Santhakumaran, L.N., A. Singh \& V.T. Thomas (1995). Description of a sacred grove in Goa (India), with notes on the unusual aerial roots produced by its vegetation. Wood (October-December): 24-28.

Santhakumaran, L.N., A. Singh \& V.T. Thomas (1996). Further notes on the sacred grove at Bamber in Goa (India). Wood (April-June): 6-7.

Sasidharan, N. \& V.V. Sivarajan (1996). Flowering Plants of Thrissur Forests. Scientific Publishers, Jodhpur, 265-266pp.

Singh, S.N. (1996). Ecogeographical Surveying for In Situ Conservation of Wild Relatives of Cultivated Plants in Uttara Kannada District of Karnataka State, India. PhD Thesis. Centre for Ecological Sciences, Indian Institute of Science, Bangalore.

Talbot, W.A. (1911). Forest Flora of the Bombay Presidency and Sind - Volume II. Government Photozincographic Press, Poona, 574pp.

Vasudeva, R., H.B. Raghu, Dasappa, R.U. Shaanker \& K.N. Ganeshaiah (2001). Population structure, reproductive biology and conservation of Semecarpus kathalekanensis: A critically endangered freshwater swamp tree species of the Western Ghats, pp. 221-223. In: Shaanker, R.U., K.N. Ganeshaiah \& K.S. Bawa (eds.). Forest Genetic Resources, Status, Threats and Conservation Strategies. Oxford \& IBH, New Delhi.

World Conservation Monitoring Centre (1998). Myristica magnifica. In: IUCN 2012. IUCN Red List of Threatened Species. Version 2012.1. <www.iucnredlist.org>. Downloaded on 29 September 2012. 